\title{
Carnaval como direito: \\ A Revolta Canboulay de 1881, em Port-of-Spain, Trinidad.
}

Eric Brasil ${ }^{1}$

Resumo: Este artigo busca compreender as formas de participação e organização da população negra, a racionalidade e os sentidos políticos de suas lutas pela manutenção de direitos e autonomia através da análise da Revolta Canboulay do Carnaval de 1881, ocorrida na cidade de Port-of-Spain, capital da então colônia britânica de Trinidad, no Caribe. Os foliões negros precisaram dialogar com forças sociais múltiplas - polícia, governo colonial e imprensa - que se empenharam em controlar e delimitar os sentidos dos carnavais e da participação negra na sociedade colonial. Através de fontes primárias e de bibliografia especializada, pretendemos realizar uma análise de história social da cultura, pensando a Revolta a partir das contribuições de E. P. Thompson sobre costume, direito e lei.

Palavras-chave: Carnaval; Revolta; Trinidad; Direitos

\section{Carnival as a right: The Canboulay Riot, Port-of-Spain, Trinidad, 1881}

\begin{abstract}
This work aims to understand the ways developed by the black population to participate and organize themselves, as well as the rationality and the political meanings of their struggles to keep rights and autonomy through the Canboulay Riot in the Carnival of 1881, that has occurred in Port-of-Spain, then capital of the British Caribbean colony of Trinidad. The Black revelers had to interact with multiple social forces - as the police, the colonial government and the press - which fought to control and delimitate the meanings of the carnival and the participation of Blacks in the colonial society. Through primary sources and specialized bibliography, we plan to conduct an analysis of social history of the cultural forms, which understands the Canboulay Riot from the contributions of E. P. Thompson's work about customs, right and law.
\end{abstract}

Keywords: Carnival; Riot; Trinidad; Rights

Artigo recebido em: 18/01/2016

Artigo aprovado para publicação em: 02/04/2016

\footnotetext{
${ }^{1}$ Mestre e Doutor pelo Programa de Pós-Graduação em História da Universidade Federal Fluminense. Este artigo é um recorte da tese Carnavais Atlânticos: cidadania e cultura negra no pós-abolição. Rio de Janeiro e Port-ofSpain, Trinidad (1838-1920), fruto de pesquisa financiada pelo CNPq em arquivos no Brasil e na Inglaterra. Endereço para correspondência: Rua Noronha Torrezão, 370, Bloco 2 Apto 402, Santa Rosa, Niterói, RJ, Cep: 24240-183. E-mail: ericbrasiln@gmail.com
}

\section{CANPHLAC}

Revista Eletrônica da ANPHLAC, ISSN 1679-1061, №. 20, p. 48-77, Jan/Jun., 2016.

http://revista.anphlac.org.br 
A Revolta Canboulay [Canboulay Riot], ocorrida em 1881 na cidade de Port-of-Spain, capital da então colônia britânica de Trinidad, foi um marco na história de seu carnaval. Entretanto, sua importância extrapola os dois dias consagrados a Momo na ilha caribenha. Neste artigo, buscamos compreender as formas de participação e organização da população negra e a racionalidade política de suas lutas pela manutenção de direitos e autonomia através da Revolta e como enfrentaram as diferentes forças sociais - polícia, governo colonial e imprensa - que se empenharam em controlar e delimitar os sentidos dos carnavais e da participação negra na sociedade colonial.

A análise desse evento se mostra ainda mais importante pelo fato de o carnaval ter se tornado ao longo do século XX a festa símbolo da ilha e atualmente é elemento central na identidade nacional da República de Trinidad e Tobago. ${ }^{2}$ Outrossim, é relevante para pensarmos transnacionalmente mobilizações negras em outras cidades atlânticas, como é o caso das experiências negras cariocas na Primeira República. ${ }^{3}$

Um amplo conjunto de fontes foi recolhido e analisado para que tais objetivos fossem alcançados. Parte significativa da documentação aqui trabalhada se encontra no The National Archives, em Londres, Reino Unido, no fundo Records of the Colonial Office, Commonwealth and Foreign and Commonwealth Offices, Empire Marketing Board, and related bodies relating to the administration of Britain's colonies. ${ }^{4}$ Os jornais Port-of-Spain Gazette e The Mirror, e inúmeros folcloristas e memorialistas, cujos exemplares encontram-se preservados na British Library, também foram analisados.

Atualmente, encontramos uma vasta bibliografia sobre o carnaval de Trinidad. Teses, livros e artigos produzidos desde os anos 1960 vêm buscando compreender a importância da festa para a formação da identidade nacional, a resistência à dominação e ao racismo colonial, e um grande número de trabalhos buscando mostrar as sobrevivências africanas nas formas carnavalescas de Trinidad. Dentre os trabalhos mais importantes está o livro de John Cowley

\footnotetext{
2 Trinidad só seria unida a Tobago em 1899, tornando-se uma única colônia, compartilhando toda a administração. Sua independência do Império britânico viria apenas em 1962, quando se tornaria a República de Trinidad e Tobago (WOODING, 1960).

${ }^{3}$ Esse artigo é parte do capítulo seis de minha tese de doutorado, cujo objetivo principal é pensar as experiências negras de Port-of-Spain e Rio de Janeiro no Pós-Abolição transnacionalmente (BRASIL, 2016).

${ }^{4}$ CO 295 - Colonial Office and Predecessors: Trinidad Original Correspondence: CO 295/289-293; CO 295/301; CO 295/304-5; CO 295/309-10; CO 295/317; CO 295/321; CO 295/332; CO 295/426; CO 297 - War and Colonial Department and Colonial Office: Trinidad: Acts: CO 297/13; CO 884 - War and Colonial Department and Colonial Office: West Indies, Confidential Print.
}

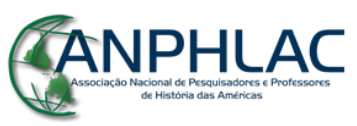


(2003), o qual aborda desde a abolição da escravidão (1838) até a segunda década do século $\mathrm{XX}$, mostrando as transformações do carnaval e sua relação com o desenvolvimento do Calypso - gênero musical característico da ilha. Entretanto, busco empreender uma análise que aproxime a história social do estudo das formas culturais, especificamente inspirada nas contribuições de E. P. Thompson (1998) sobre costume, direito e lei. Acredito que dessa forma podemos compreender mais claramente os sentidos da Revolta para os próprios foliões negros.

\section{Introdução à História de Trinidad (1498-1838)}

Localizada a aproximadamente vinte quilômetros do litoral da Venezuela, possuindo em torno de três mil quilômetros quadrados, a ilha de Trinidad não despertou muita atenção de seus conquistadores espanhóis ao longo do século XVI. Os espanhóis estavam por demais interessados em extrair até o último grama de ouro e prata de outras ilhas e de suas colônias continentais, especialmente aquelas situadas nos territórios dos antigos impérios Asteca e Inca. Até às últimas décadas do século XVIII, a ilha de Trinidad viveu basicamente do cultivo de tabaco e cacau utilizando indígenas escravizados (LIVERPOOL, 2001, p.28; WILLIAMS, 1964, p.18).

Nos séculos XVII e XVIII, a ilha vivenciou algumas tentativas infrutíferas de implementação de plantations de tabaco e cacau, que apesar de abrirem alguma demanda ao tráfico de africanos escravizados, não obtiveram êxito no período de domínio espanhol (MATTHEWS, 2007, p. 87-89). Na década de 1780, o Rei espanhol assinou a "Cedula de Poblacion" permitindo que estrangeiros de nações amigas se estabelecessem em Trinidad, desde que professassem sua religião Católica Romana. A partir de então se intensificou a imigração de proprietários franceses, que chegavam à ilha acompanhados de seus escravos (WOODING, 1960, p. 144). Essa migração foi impulsionada pela Revolução Francesa (1789) e pela Revolução do Haiti (1791), visto que muitos proprietários franceses que viviam em Santo Domingo buscaram asilo em Trinidad. Isso explica a existência de uma poderosa classe de proprietários rurais francófonos numa ilha que nunca pertenceu à França.

No contexto das guerras napoleônicas e da aliança entre Espanha e França, a coroa britânica decidiu conquistar a ilha de Trinidad como parte de sua estratégia de guerra, visto que esta ocupava uma posição importante de base de comércio com as demais colônias espanholas. Em 1797, “[...] com poucos barcos para defender a colônia, e com a Espanha incapaz de enviar

\section{CANPHLAC}


navios de guerra e homens [...]", o Governador Don Chacon se rendeu aos britânicos (LIVERPOOL, 2001, p. 30; BRADING, 1984, p. 434-5; WADDELL, 2004).

Segundo Eric Williams (1964, p. 47), ao chegarem a Trinidad em 1797, os britânicos encontraram uma população de 17.643 pessoas. Dentre eles, 2.086 brancos ( 929 homens); 4.466 "pessoas livres de cor" (1.196 homens); 1.082 ameríndios (305 homens); 10.009 "escravos negros" (4.164 homens). Esse elevado número de pessoas escravizadas se explica pela intensa migração de fazendeiros franceses ao longo das décadas de 1780 e 1790 (WILLIAMS 1964, p. 47). Os números apontados pelo historiador Hollis Chalkdust Liverpool (2001, p. 31) para 1803 revelam um aumento da população geral:

Tabela 1. População de Trinidad - 1803. Fonte: Hollis Chalkdust Liverpool, p. 31

\begin{tabular}{|l|l|l|l|l|}
\hline & \multicolumn{1}{|c|}{ Brancos } & Pessoas de cor & Escravizados & \\
\cline { 1 - 3 } Ingleses & 663 & 599 & & \\
\cline { 1 - 3 } Espanhóis & 605 & 1.751 & & \\
\hline Franceses & 1.093 & 2.925 & & \\
\hline Total & $2.361(8,4 \%)$ & $5.275(18,7 \%)$ & $20.464(72,9 \%)$ & $28.100(100 \%)$ \\
\hline
\end{tabular}

Por mais que esses números possam não representar a realidade devido às grandes dificuldades na realização de censos precisos, eles demonstram que em poucos anos a colônia recebera um número acentuado de africanos escravizados. Podemos notar a predominância francesa tanto entre a população branca quanto entre as "pessoas de cor livres"5. Estes últimos, já no início do século XIX, compõem parcela significativa da população, com número maior do que o de brancos. Muitos deles vinham das ilhas caribenhas controladas pela França e se estabeleceram como pequenos proprietários de terra.

Assim, a nova administração colonial precisaria lidar com uma sociedade dividida entre proprietários franceses de terra e de escravos e seus descendentes; "pessoas livres de cor", na maioria, culturalmente próximos da tradição francesa, muitos deles filhos ilegítimos de colonos, possuindo diferentes tons de pele; e os africanos escravizados vindos sobretudo da Costa

\footnotetext{
${ }^{5}$ Esse termo é comum na documentação britânica e se refere à população negra ou de descendência africana que nascera livre ou conquistara a liberdade.
}

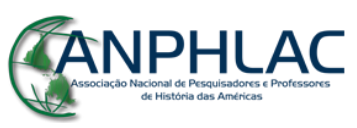

Revista Eletrônica da ANPHLAC, ISSN 1679-1061, №. 20, p. 48-77, Jan/Jun., 2016.

http://revista.anphlac.org.br 
Ocidental da África, formando a maioria esmagadora da população (em torno de $73 \%$ em 1803).

A primeira metade do século XIX em Trinidad foi sobremaneira marcada pelos debates sobre a abolição do tráfico de africanos escravizados e a abolição da escravidão. Sendo uma colônia recém-conquistada pelos ingleses, Trinidad ocupou o centro de tais discussões (FERGUS, 2013; FERGUS, 2009). Após a abolição definitiva da escravidão em 1838, os debates sobre trabalho livre e cidadania se intensificaram. A Ilha foi alvo de pujante política de imigração de trabalhadores contratados, que ficavam presos à terra através de dívidas indentured labourers - vindos especialmente da Índia, chamados de coolies (WILLIAMS, 1964; SAMAROO, 2011; CLARKE, 2011). A sociedade Pós-Abolição de Trinidad recebeu também milhares de imigrantes das demais ilhas caribenhas em busca de melhores condições de vida e oportunidades de trabalho.

\section{Carnaval Jamette e o Canboulay}

As intensas transformações sociais experimentadas no Pós-Abolição de Trinidad também impactaram nas formas de mobilização negra nos embates, diálogos, negociações e enfrentamentos com as autoridades coloniais, com os imigrantes das variadas regiões do mundo e com as elites locais anglófonas, mais ligadas às forças metropolitanas, e francófonas, descendentes dos proprietários de terra e escravos do período anterior à conquista inglesa.

Uma das práticas carnavalescas mais associadas às experiências negras urbanas de Portof-Spain foi o Canboulay. Esse termo teria sua origem ligada a um expediente comum nas plantations de cana-de-açúcar, associado ao uso de fogo, incêndios controlados e estratégias para controlar incêndios realizadas pelos escravos das fazendas. O termo deriva da expressão francesa Cannes Brulées [Cana queimada]. O termo francês seria transformado pela língua crioula em Canboulay e assim entraria para a história do carnaval.

Nos carnavais das décadas iniciais do século XIX, uma das mais "divertidas" formas de brincar para a "plantocracia" [fazendeiros proprietários de terras] branca francófona da ilha era a encenação de uma paródia das práticas dos escravizados, zombando de suas danças, formas

\section{CANPHLAC}


estéticas, fala e características físicas. $\mathrm{O}$ auge dessa performance acontecia com a encenação de um Cannes Brulées, com brancos pintados de negros.

Entretanto, após a abolição da escravidão, o Canboulay foi aos poucos incorporado e recriado a partir das experiências negras da cidade, extrapolando os sentidos racistas da sátira senhorial. O Canboulay passou a catalisar uma série de práticas e tradições negras que remontavam às memórias da África e do cativeiro, mais do que apenas uma atualização da sátira realizada pelas elites francófonas anteriormente. ${ }^{6}$

A população mais pobre da cidade, moradora das chamadas Barrack Yards - grandes casarões, com pátio interno, onde os cômodos eram divididos entre várias famílias, numa configuração semelhante aos cortiços do Rio de Janeiro do mesmo período -, entre as décadas de 1840 e 1870, desenvolveu e ampliou os grupos de Canboulay, constituindo-se como uma das principais estratégias de formação de identidades e como uma das centrais características dos carnavais da cidade. Os sujeitos responsáveis pela criação e manutenção desses grupos eram homens e mulheres negros trabalhadores urbanos, jovens, vivendo em dificílimas condições de vida, disputando empregos, água, amores, prestígio com os demais grupos de outras Barrack Yards. Foram chamados de Jamettes pelos contemporâneos e assim entraram para a história.

Atualmente, em Trinidad, jamette significa prostituta, contudo, nos carnavais de meados do século XIX seu significado era muito mais amplo. O termo tem origem no francês diametre, e em patois jamette, diâmetro. Esse termo designaria o grupo de pessoas localizado "abaixo do diâmetro da respeitabilidade", aqueles representantes do "submundo" da cidade: prostitutas, criminosos, cantores, tocadores de tambor, dançarinos, stickmen [homens que duelavam com cacetes de madeira], ${ }^{7}$ obeahmen [curandeiros e feiticeiros afro-caribenhos] (PEARSE, 1956). Os grupos que se formavam no seio da população considerada Jamette, moradores das Barrack Yards, apresentavam performances públicas com conteúdo sexualizado e abertamente desafiador para os padrões de moralidade defendidos pelas elites coloniais. ${ }^{8} \mathrm{Na}$ visão de muitos,

\footnotetext{
${ }^{6}$ Para maiores discussões sobre esse processo, ver Cowley, 1992 e Cowley, 2003.

${ }^{7} \mathrm{O}$ uso do termo cacete neste artigo se justifica pela recorrência do mesmo nas fontes sobre Rio de Janeiro para o século XIX e início do século XX, assim como por seu uso na bibliografia (ASSUNÇÃO, 2008).

${ }^{8}$ Apesar das tensões em seu interior - marcadamente a rivalidade entre franceses católicos e ingleses protestantes presente por todo o século XIX na ilha -, as elites coloniais se uniram em torno do desejo pela manutenção de um padrão rígido de ordem pública, pela defesa de um sistema de status social bastante hierarquizado - baseado tanto
}

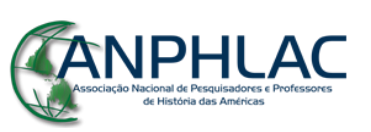

Revista Eletrônica da ANPHLAC, ISSN 1679-1061, №. 20, p. 48-77, Jan/Jun., 2016.

http://revista.anphlac.org.br 
esses grupos, que desfilavam desafiadoramente pelas ruas da capital, seriam compostos por hordas de homens e mulheres unidas para manter "a vadiagem, a imoralidade e o vício" e eram constantes moradores das prisões (PEARSE, 1956).

Para além do olhar das elites, o carnaval Jamette representou uma das mais marcantes expressões da cultura da classe trabalhadora negra da cidade, unindo tradições da África Ocidental, memórias da escravidão e da abolição e dialogando estreitamente com as transformações da vida urbana de Port-of-Spain (LIVERPOOL, 2001, p. 253). Seu carnaval era caracterizado pelo Canboulay com tambores, pelo confronto entre as diferentes Yard bands formadas e defendendo cada uma sua Barrack Yard -, com os desafios verbais, através das canções chamadas de Kalinda, e os físicos, através dos confrontos entre stickfighters, homens que lutavam utilizando pequenos pedaços de madeira [sticks]. Essa performance negra se chocava com os valores da hierarquia colonial e sua noção de civilização e acionava memórias da África, da escravidão e da abolição.

Um grupo [band] de Canboulay reunia música e canto, com a presença de orquestra com instrumentos de origem africana, especialmente tambores, protegidos no centro do préstito; uma corte real, composta de rei, rainha e príncipes, posicionava-se à frente da orquestra. Ao redor dos músicos e da corte, cerca de cinquenta homens carregavam cacetes [sticks] na mão direita e tochas na mão esquerda. Estes cantavam e protegiam os músicos e a família real. $\mathrm{Na}$ retaguarda do préstito, grupos de mulheres e crianças eram responsáveis por prover cacetes, tochas, tambores - e, se necessário, pedras e garrafas - aos stickfighters (ELDER, 1998).

O sucesso do grupo dependia da confiança e companheirismo entre os membros. Ao enfrentar um grupo rival era preciso saber que se podia contar com seus pares, que os músicos, rei, rainha e príncipe seriam protegidos, e que a reposição de artefatos seria provida com eficiência pelas mulheres e crianças. A identidade do grupo era fundamental para sua sobrevivência e destaque no carnaval. O senso de pertencimento desses grupos tinha origem na experiência social, calcada na vida muitas vezes turbulenta e agitada das barrack yards. Os grupos rivais eram geralmente originários de territórios diferentes que utilizavam o palco carnavalesco para resolver rusgas e conflitos ocorridos ao longo do ano: uma disputa por emprego, um namorada, um ato de violência ou ofensa pública.

na questão social/econômica quanto na questão racial -, nas políticas de controle da força de trabalho, na defesa do Cristianismo e da Civilização europeia como único padrão aceitável. (CROWLEY, 1956, p. 196)

\section{GANPHLAC}

Revista Eletrônica da ANPHLAC, ISSN 1679-1061, №. 20, p. 48-77, Jan/Jun., 2016.

http://revista.anphlac.org.br 


\section{A revolta do Canboulay de 1881}

No ano de 1877, o Capitão Arthur Baker foi indicado pelo Secretary of State for the Colonies $^{9}$, autoridade responsável pelo Colonial Office, para ocupar o cargo de Inspetor Comandante da Força Policial de Trinidad. Baker havia servido no exército britânico na Costa do Ouro, na África, e participado das guerras contra os Axantes naquela região. Na verdade, as fontes mostram que Baker se aposentou no Exército com a patente de tenente, e que fraudulentamente reivindicou o posto de Capitão (TROTMAN, 1986, p. 92).

Essa bagagem militar e colonial influenciou em sua escolha para o cargo. Capitão Baker substituiria L. M. Fraser como Inspetor Comandante e assumiria com a missão de submeter as classes baixas [lower classes] à lei e à ordem, tarefa cujo antecessor teria sido incapaz de cumprir. ${ }^{10}$ (COWLEY, 2003, p. 73; LIVERPOOL, 2001, p. 303-304). O cargo de Inspetor Comandante ocupado por Baker entre 1877 e 1889 correspondia ao comandante geral das forças policiais de toda a colônia, tendo sua sede na capital Port-of-Spain. Era uma posição indicada pelo Colonial Office, assim como o próprio Governador.

Com o argumento de manter a lei e a ordem e controlar a criminalidade, "a polícia declarou guerra ao público em todas as frentes" sob o comando de Baker (TROTMAN, 1986, p. 92). Dessa maneira, Baker estabeleceu como prioridade o combate ao carnaval negro das ruas de Port-of-Spain. Nos anos de 1878 e 1879, ele liderou a polícia numa estratégia para conter os desafios de cacetes: efetuou inúmeras prisões, colocou guardas armados nos lugares onde as bandas costumavam se encontrar e ele mesmo realizou constantes rondas a cavalo pela cidade. Em 1880, com amplo apoio dos principais jornais - que elogiavam seu empenho e sucesso em diminuir as características reprováveis do Carnaval -, e com suporte de parte da elite local, especialmente daqueles britânicos e descendentes ligados à administração colonial, Baker decidiu ampliar sua estratégia repressiva e ordenou que as tochas, tambores e cacetes

\footnotetext{
${ }^{9}$ O Secretary of State for the Colonies era o ministro chefe do Colonial Office, responsável pela gestão das várias colonias do Reino Unido ao redor do mundo.

${ }^{10}$ Fraser produziria nas últimas décadas do século XIX obras memorialísticas e de história de Trinidad. O comandante de polícia ligado à produção intelectual sofreu duras críticas por parte das elites coevas, pois não seria rígido o suficiente com as práticas "bárbaras" da população.
}

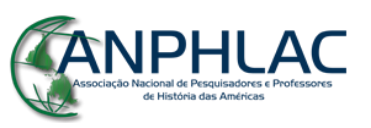

Revista Eletrônica da ANPHLAC, ISSN 1679-1061, №. 20, p. 48-77, Jan/Jun., 2016.

http://revista.anphlac.org.br 
fossem apreendidos pela polícia e estabeleceu que as bandas seriam acompanhadas por policiais onde quer que fossem (COWLEY 2003, p. 82; LIVERPOOL 2001, p. 304).

Em 1880, Capitão Baker apreendeu as tochas dos grupos [bands] durante a primeira noite de Carnaval. Tal medida estava calcada numa lei do Conselho Legislativo de 1868 que proibia seu uso em procissões e festas púbicas. Pegos de surpresa, os membros dos grupos entregaram as tochas e submeteram suas práticas ao controle da polícia naquele ano.

No carnaval seguinte, impulsionado pelo 'sucesso' do ano anterior, Baker decide fazer nova investida contra os grupos que carregavam tochas - um dos elementos centrais do Canboulay -, e além de apreendê-las, pretende impedir que esses grupos transitem nas ruas sem acompanhamento policial.

Contudo, os grupos [bands] tradicionalmente rivais (que anualmente se enfrentavam nas ruas em duelos com cacetes [sticks]) se unem para resistir à polícia. Quando os policiais tentam subjugar os masqueraders, estes resistem e o confronto se inicia por volta da meia-noite do dia 27 de fevereiro de 1881. O termo masquerader não significa apenas o indivíduo mascarado. Ele tem significado mais amplo, englobando toda uma performance que envolve dança, fantasia e música. Neste artigo, podemos traduzir masqueraders por foliões negros, pois, como veremos adiante, os sujeitos tratados com esse adjetivo nas fontes eram, em sua ampla maioria, negros residentes em Port-of-Spain no período estudado.

Grupos de subúrbios afastados e de outras cidades se reuniram em Port-of-Spain especialmente para enfrentar a polícia. Dezenas de pessoas ficaram feridas. A população que assistia também participou atacando a polícia, inclusive das sacadas dos prédios. Pedras e garrafas foram previamente estocadas em esquinas e becos para prover os carnavalescos de "munição" para o confronto. Um dos policiais chega a utilizar seu sabre contra a multidão $[m o b]$, ferindo gravemente um participante. Em torno de três e meia da madrugada, a polícia consegue dispersar a população e, com as ruas mais calmas, retorna para o quartel.

Por volta das seis e meia da manhã do dia 28 de fevereiro de 1881, o Governador Sanford Freeling recebe no Queen's House, a sede do governo, o Capitão Baker, que o informa dos acontecimentos e pede que tropas do exército sejam convocadas para ajudar a polícia. $\mathrm{O}$ governador convoca prontamente uma reunião ex traordinária com o Conselho Executivo ${ }^{11}$ onde

\footnotetext{
${ }^{11}$ O Conselho Executivo era "um corpo puramente consultivo, compreendendo o Secretário Colonial, o Procurador Geral e o Tesoureiro Colonial, tendo o Governador como presidente". (WOODING 1960, p. 150)
}

\section{GANPHLAC}

Revista Eletrônica da ANPHLAC, ISSN 1679-1061, №. 20, p. 48-77, Jan/Jun., 2016.

http://revista.anphlac.org.br 
fica decidido que cinquenta sodados do $4^{\circ}$ regimento serão requisitados para apoio na cidade estes chegam ao quartel da polícia por volta das dez horas da manhã do dia 28 de fevereiro - e um edital para a convocação de guardas especiais seria publicado naquela mesma tarde.

O Conselho Executivo recebe também a visita de representantes do Conselho Municipal. Eles alertam sobre a grande comoção e assombro presente na população e a iminente ameaça à ordem e à propriedade privada. Perante as informações apresentadas, o governador Sanford Freeling decide ir falar diretamente com o povo na praça do mercado da Rua George. Os membros do Conselho Municipal afirmam que tal medida surtiria mais efeito "do que mil soldados nas ruas" e seria capaz de aplacar o clima de insatisfação e revolta que se alastrara entre a multidão $[\mathrm{mob}]$.

Às cinco da tarde do dia 28, o Governador Freeling discursa para as pessoas reunidas na praça pública e promete que a polícia não mais interferiria no carnaval e que permaneceria recolhida em seu quartel. O povo poderia continuar a festa, desde que demonstrando lealdade ao governo e de forma ordeira. Sob aplausos, teria sido, então, selado um acordo simbólico entre o Governador e os carnavalescos negros.

Após esse inusitado encontro, à polícia é dada a ordem de se recolher e a festa continua. Cortejos com tochas, instrumentos musicais e risadas percorrem as ruas do centro da cidade. Um grupo passa em frete ao quartel da polícia cantando o refrão "A polícia não pode fazer isso". É realizado um enterro carnavalesco de um boneco representando o Capitão Baker. Sem polícia nas ruas, a festa prossegue sem mais conflitos.

Ao término do carnaval de 1881, com um saldo de dezenas de presos e feridos, teve início uma verdadeira guerra de versões sobre a Revolta. Polícia, imprensa e governo colonial produziram interpretações múltiplas, muitas vezes divergentes, sobre o que aconteceu e sobre quais medidas deveriam ser tomadas dali pra frente. Pretendo analisar essas versões atentando para os agentes que produziram tais fontes e suas diferentes inserções sociais em Port-of-Spain.

\section{Capitão Baker e a polícia de Port-of-Spain.}

Com apoio da força policial sob seu comando, Baker mantém sua postura de correção e firmeza ao responder a um conjunto de 16 perguntas redigidas pelo Governador Freeling e

\section{CANPHLAC}


endereçadas ao Inspetor de Polícia pelo secretário colonial, Busche. As perguntas chegam para Baker no dia 12 de março de 1881. No dia 21 de março, as respostas estavam nas mãos do governador e quatro dias depois foram envidas para o Colonial Office, em Londres (CO 295 289 49). As linhas traçadas por Baker nos possibilitam interpretar com mais profundidade sua lógica e argumentação para justificar suas ações.

Baker inicia afirmando que havia rumores de que os grupos pretendiam carregar tochas acesas pela cidade, mas que, como no ano anterior haviam pacificamente entregado suas tochas ao primeiro aviso da polícia, ele "não tinha sérios motivos para crer que eles agiriam diferentemente nesta ocasião" (CO 295289 49). Consciente de sua atitude correta, a resposta do capitão a uma possível ação indevida da polícia, sugerida pelo governador na pergunta três, foi a seguinte:

[Baker]. 3. A Polícia nesta ocasião não interferiu indevidamente com o Carnaval, os mesmos passos que foram tomados esse ano foram tomados ano passado. A Polícia simplesmente recebeu ordens para impedir o transporte de tochas acesas pelas ruas. Estas medidas foram altamente aprovadas no ano passado pelo Executivo e pela comunidade em geral. (CO 295289 49)

Em sua interpretação, as ações da polícia não se justificavam apenas pelo suporte da lei, mas também pela aprovação do poder Executivo e "pela comunidade em geral", notadamente os elogios recebidos pela totalidade da imprensa nos anos de 1878, 1879 e 1880. Na tentativa de deixar evidente que as ações de 1881 não diferiam daquelas tomadas nos anos anteriores, Baker afirma que não foram tomadas medidas específicas para preparar a Polícia para um confronto.

O governador avança em seus questionamentos e traz à tona a questão da impressão corrente nas ruas de que a polícia pretendia extinguir o Cannes Brulées. Pergunta diretamente para o Inspetor: "Houve qualquer anúncio público deste dado ou foi de conhecimento geral do Corpo de Polícia de que este era para ser o caso"? (CO 295289 49) Em resposta, Baker diferencia "Cannes Brulées" de "Carnaval", e apresenta um novo dado sobre a divulgação e debates nas ruas da cidade sobre o que esperar daquele carnaval:

[Baker] 5. Se o termo Cannes Brulées significa carregar tochas acesas pelas ruas, a impressão de que seria evitada como no ano passado deve ter se espalhado.

\section{GANPHLAC}


Se o termo significa "Carnaval" sem tochas acesas, eu não consigo dizer como tal impressão pode ter se espalhado exceto através de um cartaz manuscrito anônimo que foi postado na cidade alguns dias antes do Carnaval, e foi trabalhada da seguinte forma:

"Notícias aos Trinitários [Trinidadians]

Capitão Baker exigiu de nosso nobre e tranquilo Governador Sir Sanford Freeling, Sua Excelência, para impedir a noite de Canboulay. Mas a nossa Excelência exige[?]." (CO 295289 49)

Como agente da lei e da ordem, Baker afirma não ter tido intenção de acabar com o Carnaval como um todo, mas apenas com as práticas ilegais que o formavam. Se a ideia de extinção do carnaval ganhou as ruas, isso se devia à atitude má intencionada dos autores de cartazes como o supracitado, visando jogar o povo contra a polícia e proteger o governador. Além do mais, em sua concepção, não havia necessidade de explicitar no Edital regularizando o carnaval de 1881 a proibição do porte de tochas acesas nas ruas, pois tal prática já era proibida por lei desde 1868 .

O tema das tochas se torna central nesse "diálogo" entre governador e Inspetor de Polícia. Freeling indaga:

[Governador]. 11. Que a supressão das tochas foi uma surpresa pois as pessoas pensavam que o Carnaval sendo permitido, eles tinham o direito de carregar suas tochas. (CO 295289 49, grifos meus)

Baker refuta tal ponto, argumentando que os grupos não teriam se "amalgamado", coisa sem precedente, e "preparado o seu ataque contra a polícia" se a proibição das tochas tivesse sido uma surpresa para eles. "As tochas foram extintas em 1880, o que foi naturalmente lembrado." (CO 295289 49)

Com a insistência de Freeling, que claramente tenta, através de suas perguntas, indicar que o porte de tochas era uma prática antiga e bastante valorizada pelos masqueraders, Baker aumenta o tom áspero nas respostas. Freeling escreve em sua décima segunda questão: "a prática de carregar tochas havia prevalecido mais de meio século sem que qualquer incidente tivesse ocorrido". (CO 295289 49) A resposta de Baker demonstra impaciência e mesmo um ar de insubordinação, evidenciando a tensão entre as duas autoridades naquele momento:

[Baker] 12. Eu não estou ciente de quanto tempo a prática tem prevalecido nem que acidentes podem ter acontecido por conta dela durante meio século. A portaria

\section{GANPHLAC}


impedindo o uso das tochas acesas nas ruas foi (sic) passou em 1868. (CO 295289 49).

A discordância entre eles cresce ainda mais quando o Governador coloca em xeque a competência da polícia em controlar a situação: "Que a polícia estava completamente incapaz de lidar com as pessoas" (CO 295289 49), escreve Freeling, aguardando a resposta do Inspetor.

[Baker] 14. Isso eu nego, quando a polícia voltou aos seus quartéis às 4 da manhã do dia 28 de Fevereiro, as ruas estavam então perfeitamente calmas, e a polícia teve a Cidade sob controle perfeito. Trazer os Militares foi simplesmente um ato de precaução, que eu ainda acho que foi acertado, e o fato de ser conhecido que eles estavam nos quartéis - não tivesse a Polícia sido retirada das ruas - teriam erradicado o "Cannes brulées" para sempre. (CO 295289 49, grifos meus)

O desfecho dessa inquirição não poderia ser mais tenso. O Inspetor Comandante conclui que a polícia havia dado conta dos distúrbios, controlado a cidade perfeitamente. E que se "não tivesse a Polícia sido retirada das ruas" através de uma ordem expressa do Governador, eles teriam alcançado o êxito total no cumprimento de uma lei aprovada há 13 anos e que nunca ninguém teve capacidade de implementar satisfatoriamente. O Cannes Brulées, a prática bárbara, incivilizada e obscena, que tanto perigo trazia para a cidade material e culturalmente teria sido "erradicada para sempre", não fosse a submissão do Governador Freeling ao desejo e pressão dos masqueraders.

\section{Governador e Conselho Municipal contra Polícia: leituras da Revolta}

Como ficou evidente na análise do documento acima, a autoridade que mais antagonizou as ações e medidas do Capitão Baker foi o recém empossado Governador Sanford Freeling. Ele havia chegado à ilha em meados do ano de 1880 e logo em seu primeiro carnaval no cargo enfrentou a Revolta Canboulay. Teve pouco tempo de se inteirar das práticas e costumes do povo que estaria fadado a governar, mas assim que a revolta estourou Freeling teve certeza que aumentar a repressão apenas acirraria os ânimos e talvez levasse a um conflito sem precedentes na história da colônia. Localizado entre o Colonial Office, a quem deveria prestar constante

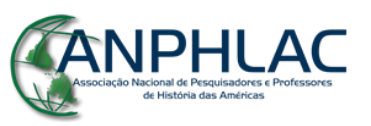

Revista Eletrônica da ANPHLAC, ISSN 1679-1061, №. 20, p. 48-77, Jan/Jun., 2016.

http://revista.anphlac.org.br 
satisfação, e as forças políticas locais, às quais ele ainda não estava totalmente integrado, Freeling precisou definir rapidamente sua estratégia de ação diante da revolta.

Relatando os acontecimentos ao Conde de Kimberley, Secretário de Estado para as Colônias ente 1880 e 1882, Freeling afirma ter sido informado da intensão de Baker em "por um fim" ao uso de tochas no carnaval, visto que havia impedido seu uso no carnaval de 1880 sem resistência. Freeling relata ao seu superior que, ao ficar sabendo dessa informação, pediu ao Secretário Colonial, Busche, que comunicasse o Capitão Baker de que ele

\begin{abstract}
não queria que essa prática fosse encerrada sem [sua] autorização. Infelizmente, entretanto, a ordem não foi dada [?], conforme fui avisado pelo Secretário Colonial, pelo fato de Capitão Baker estar doente [...] [No dia 26/02, um dia antes do carnaval, o Inspetor Comandante Baker disse ao Governador que] a polícia iria apenas observar o povo e não iria interferir com eles a não ser que um distúrbio ocorresse. Eu [governador] não dei a ele [a informação] sobre a não proibição das tochas, imaginando que minha ordem tivesse sido transmitida. (CO 295289 29)
\end{abstract}

Na documentação enviada ao Colonial Office, Freeling pretende deixar evidente que a ordem de impedir o uso de tochas naquele carnaval não havia partido dele. Muito pelo contrário, ele havia dito expressamente que essa medida não deveria ser tomada sem sua autorização. Entretanto, sua ordem não foi dada a Baker; esse, por sua vez, não comunicou ao governador sua intensão de impedir por completo o porte de tochas - se não mentiu, pelo menos omitiu a informação. A autoridade do novo governador estava sendo publicamente ameaçada pelo Inspetor Comandante de Polícia, fato potencializado pela incompetência do Secretário Colonial, incapaz de transmitir suas ordens.

Após receber a notícia dos distúrbios na manhã do dia 28 de fevereiro, Freeling se reuniu com o Conselho Executivo e recebeu o Conselho Municipal. Sua estratégia foi definida nessas reuniões, conquistando pleno apoio do Conselho Municipal. Esse órgão havia sido criado em 1853 e era o único corpo administrativo eletivo na cidade (COWLEY, 1992, p. 327). Segundo Cowley (1992), o Conselho Municipal representava um fórum da elite local, abrigando comerciantes, proprietários de terra e prédios, donos de jornais da elite crioula francófona [french-speaking creoles $]^{12}$. Muitos desses homens estabeleceriam uma relação mais amistosa

\footnotetext{
12 O Conselho Municipal foi extinto em 1899, quando a cidade passou a ser administrada por um grupo de comissários indicados pelo governador. Ao longo das décadas de 1900 e 1910, a elite local se empenharia em retomar um espaço de representação, o que só aconteceria em 1914.
}

\title{
CANPHLAC
}

Revista Eletrônica da ANPHLAC, ISSN 1679-1061, №. 20, p. 48-77, Jan/Jun., 2016.

http://revista.anphlac.org.br 
com o Carnaval, desempenhando muitas vezes um papel de patronagem e proteção, principalmente após 1900 (COWLEY, 1992, p. 333, 537; BRERETON, 2002, p. 163; DUDLEY, 2007, p. 211).

Ao final do século XIX, houve também o crescimento mais acelerado de uma classe média negra e de cor [black and coloured]. Alguns descendiam da classe dos "livres de cor" de origem francesa chegados ainda no período da escravidão, mas a maioria era descendente de escravos, de imigrantes da África e do Caribe. Esse crescimento se deu muito em função do acesso à educação primária e o consequente acesso desses sujeitos a profissões um pouco mais prestigiadas e que lhes permitia o acúmulo de maior quantia de capital simbólico e material. Essa classe média negra e “de cor” seria formada então por professores, jornalistas, tipógrafos, farmacêuticos, médicos, procuradores, advogados, funcionários de escritórios. Segundo Brereton:

\begin{abstract}
Educação foi a chave para todas essas profissões, o fator crucial para a ascensão gradual de uma classe media negra e de cor. Embora alguns homens de cor tenham herdado seu status de classe media, sendo descendentes de prósperas famílias de cor livres estabelecidas antes de 1838 , a maioria representa homens que se desenvolveram por esforço próprio [self-made men], ou seus filhos, que alcançaram o status de classe média principalmente através da escola. (BRERETON 2002, p. 64)
\end{abstract}

O Conselho Municipal, entretanto, constituía um espaço de representação dos interesses de uma parte da elite local vinculada à tradição crioula francesa. Uma pequena parcela dessa elite era composta por homens de cor. Contudo, a grande maioria das classes médias negras e de cor de Port-of-Spain teria que lutar muito e por muitos anos para conseguir mais espaço nas esferas de decisões políticas ${ }^{13}$.

Não obstante, mesmo que na prática esse órgão tivesse pouco poder de decisão e autonomia administrativa (cuidava basicamente de iluminação pública, do calçamento e obras), além de ser controlado por uma maioria de proprietários brancos, era um veículo importante de pressão sobre a administração colonial. Especialmente numa Colônia da Coroa como era o caso de Trinidad, ou seja, que não possuía autonomia política, sem a existência de uma Assembleia legislativa eleita; além disso, as exigências pecuniárias para se acessar o direito ao voto para o

\footnotetext{
${ }^{13}$ Sobre a classe média negra e sua participação em diferentes esferas da vida pública de Trinidad no período, ver Brereton, 2002; Cudjoe, 2003.
}

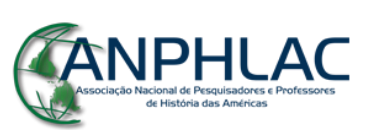

Revista Eletrônica da ANPHLAC, ISSN 1679-1061, №. 20, p. 48-77, Jan/Jun., 2016.

http://revista.anphlac.org.br 
Conselho Municipal aumentaram repetidas vezes ao longo do século XIX, reduzindo as chances da maioria em participar através do voto.

Em correspondência enviada ao Governador, o Conselho Municipal entendia que os conflitos durante o carnaval tinham um responsável evidente: Baker e sua polícia. Na carta, os conselheiros afirmam que

foi alegado que a polícia foi a primeira a iniciar os distúrbios, que eles atacaram os grupos [bands] de carnavalescos tendo como líderes os chefes de polícia que teriam desembainhado suas espadas e as brandido, e que todos eles usaram seus cacetes implacavelmente. Que passantes [bystanders] também foram atacados e feridos. (CO $29528934)$

No momento da reunião com o governador, no dia seguinte à revolta, o temor que estaria rondando o Conselho era de um possível "banho de sangue", pois a população estava indignada com a atuação da polícia. Contudo, logo revelam outro temor, tão ou mais alarmante nas mentes e corações dos membros do Conselho:

Que propriedade e famílias da burguesia foram colocadas em grande perigo por tais pessoas irresponsáveis; que não apenas um distúrbio, mas incêndios e saques foram temidos, mas não era muito tarde para fazer um apelo ao povo, e retirar por um tempo a causa da irritação para prevenir a grande calamidade. (CO 295289 34)

Portanto, visando evitar mais violência e impedir que famílias burguesas e suas propriedades fossem feridas, os conselheiros recomendavam a retirada da polícia das ruas - a "causa da irritação" e um apelo direto ao povo. Os membros se prontificavam a acompanhar qualquer autoridade, “até o Capitão Baker", numa missão de paz para fazer o povo ouvir a voz da razão. Buscavam a proteção de seus interesses econômicos, visto que muitos eram comerciantes da capital.

Munido do apoio do Conselho Municipal, Freeling escreve uma proclamação que seria publicada ainda na tarde do dia 28 de fevereiro. Nela, o governador tenta demonstrar que não aceitaria novos conflitos, mas deixa claro a tentativa de apelar para o "costumeiro bom sentimento e lealdade do povo" da cidade:

Um sério distúrbio ocorreu na última noite, um ataque realizado sobre a Polícia e considerável dano feito à propriedade do Conselho Municipal [Borough Council], o

\section{GANPHLAC}


Governador deseja que seja entendido que tais cenas de ilegalidade devem ser reprimidas.

O Governador não deseja interferir nos divertimentos e prazeres do povo, mas o porte de tochas, sendo contrário à lei e perigoso à vida e propriedade, não pode ser permitido.

O Governador está convicto de que isso será entendido e ele não irá apelar em vão para o costumeiro e bom sentimento e lealdade do povo nessa questão. (CO 295289 29, p. 291)

Dito isso, Freeling se dirige à Praça do Mercado Oriental. As palavras exatas do discurso do governador, endereçadas a uma multidão de foliões, são impossíveis de serem resgatadas exatamente. Contudo, as versões disponíveis do discurso são tão valiosas para o trabalho do historiador quanto uma impossível gravação de sua fala. O Trinidad Chronicle registrou o momento em um artigo publicado no dia 02 de março de 1881. Esse jornal, assim como as demais folhas da cidade, posicionou-se veementemente contra as ações de Baker, responsabilizando a polícia pelos conflitos.

\begin{abstract}
Às 3 da tarde, após fortes representações de membros do conselho municipal sobre os danos e perdas e quebras de lâmpadas pelos carnavalescos [masquers] em consequência da tentativa do Capitão Baker em acabar com o Canboulay, Sua Excelência se dirige ao mercado, onde foi cercado pelos principais comerciantes, membros do Conselho Municipal, advogados, oficiais, procuradores. Sobre a plataforma montada na praça, Sua Excelência discursa para o povo, dizendo que "se ele soubesse que isso [uso de tochas] era um antigo costume estabelecido do povo em brincar o Canboulay com tochas, ele não teria proibido - ele tinha pensado que as tochas eram perigosas e poderiam causar incêndios, porem ele foi informado de que elas não são propensas a fazê-lo. E acrescentou que o Capitão Baker, atacando o povo primeiro e os destratando como fez, passou inteiramente por cima de suas [governador] instruções, para o qual estava muito preocupado. Ele [Governador] estava muito surpreso que um oficial como o Capitão Baker tivesse se permitido ser arrastado em tão grave erro, que ele [Governador] deplorava. Ele [governador] disse que deu ordens para que eles [povo] não sofressem interferência, e que eles poderiam brincar o Canboulay, desde que não se comportassem de maneira ilegal [Lawless]." (CO 295289 30, grifos meus)
\end{abstract}

$\mathrm{O}$ artigo do jornal afirma que o governador Freeling esteve acompanhado no palanque por membros do Conselho Municipal, por comerciantes, advogados, donos de jornais representantes da elite crioula francesa [french-speaking creole elite]. $\mathrm{O}$ tom do discurso teria sido bastante duro no que se refere ao capitão Baker. Freeling teria nomeadamente acusado Baker diante da multidão, responsabilizando-o pelo conflito. A importância das tochas e do Canboulay teria sido reconhecida e mesmo garantida pelo governador, desde que não descumprissem leis.

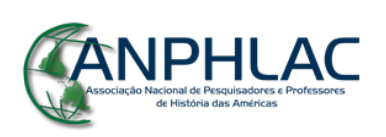

Revista Eletrônica da ANPHLAC, ISSN 1679-1061, №. 20, p. 48-77, Jan/Jun., 2016.

http://revista.anphlac.org.br 
Em seguida, o jornal afirma que o proprietário H. Billouin Esq., dono do jornal Fair Play, discursou dizendo que o povo foi ferido pelo tratamento dispensado pelas mãos da polícia, e que atacaram até mesmo espectadores que em alguns casos estavam apenas parados em suas portas. Agrediram não apenas homens, mas também crianças e mulheres. Nas palavras no jornal: "Outros discursos se seguiram, condenando fortemente a ação do Capitão Baker na noite do Canboulay." (CO 295289 30) O edital se encerra afirmando que o governador e o secretário privado teriam sido "levantados nos ombros e carregados até sua carruagem. Sua excelência retribuía com acenos com seu chapéu" (CO 295289 30).

No dia 07 de março de 1881, o governador envia ao Secretário de Estado para as Colônias uma justificativa desmentindo apenas um único ponto da matéria publicada pelo Trindad Chronicle: ele não foi carregado nos braços e não recebeu bandas no Queen's House, assim como não distribuiu refrescos para os carnavalescos na casa do governo. É significativo que ele não tenha desmentido o teor do discurso como publicado no jornal, negando textualmente apenas a notícia de que tivesse sido carregado nos braços pela multidão.

Nesse mesmo dia, segue sua própria versão do acontecimento e do referido discurso. Era 07 de março, uma semana após a revolta, e esse era o primeiro conjunto de informações enviadas ao Colonial Office. Freeling registrou assim sua fala diante do povo na praça do mercado:

Eu disse que aparentemente algum mal-entendido ocorreu sobre os desejos do Governo; que não havia desejo em parar seus divertimentos [mas?] que o uso de tochas era perigoso durante clima seco; que esperava que eles pudessem não usá-las e pudessem preservar a ordem, que se eles pudessem me prometer isso eu confiaria neles e retiraria a Polícia [das ruas]. Houve altos gritos de "nós prometemos" e saudações sendo dadas à Rainha. Eu retornei em meio a grande entusiasmo. (CO 295 $28929)$

Justifica sua promessa em retirar a polícia das ruas com base na percepção de que a presença da polícia tinha um efeito exasperador na população. Temia que à noite um novo confronto ocorresse, e que as Tropas Militares, mantidas de prontidão, fossem convocadas para agir e os danos fossem inevitáveis até que a multidão dispersasse. Ele argumentou que, como os quartéis eram no centro da cidade, a polícia e as tropas teriam todas as condições de agir em caso de emergência. Além da quebra de algumas lâmpadas públicas, Freeling relata ao Colonial Office que não houve mais danos à vida ou à propriedade após essa medida. "Entretanto,

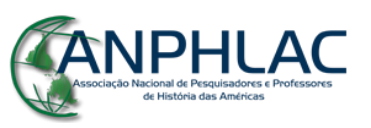

Revista Eletrônica da ANPHLAC, ISSN 1679-1061, №. 20, p. 48-77, Jan/Jun., 2016.

http://revista.anphlac.org.br 
desfilando em frente ao Quartel da Polícia, carregando tochas, e zombando, eles [masqueraders] fizeram um funeral satírico do Capitão Baker. Daquele momento até o fim do carnaval nem mesmo esse tipo de demonstração ocorreu e tudo foi ordeiro em Port-of-Spain." (CO 295289 29) Aparentemente, Freeling não entendeu como um desafio ou demonstração de poder o funeral simbólico que se encerrou com a queima de uma efígie do Inspetor Comandante em frente a seu lugar de trabalho perante seus comandados.

Apesar da clara tensão entre Freeling e Baker, o governador afirma que o Inspetor Comandante de Polícia sempre se dirigiu a ele de forma respeitosa, mantendo a ordem quando do discurso na praça do mercado e retirando suas forças quando ordenado, mesmo que "Baker pensasse que nenhum novo distúrbio ocorreria, e que a ação do governador [de retirar a polícia] poderia levar a interpretação equivocada, fazendo com que o povo não tivesse o mesmo respeito pela autoridade policial como antes". Entretanto, Freeling acreditava que tomara as medidas mais acertadas para evitar riscos sérios. "Sem dúvida o povo estava perigosamente excitado e se sangue tivesse sido derramado, um espírito de desafeto teria se criado nessa Colônia que levaria anos para recuperar." (CO 295289 29)

Construída em aliança com parte da elite crioula francesa e a maioria dos jornais locais, a estratégia do governador Sanford Freeling colocou como alvo principal minimizar os conflitos violentos e isolar a polícia comandada por Baker como resposta à insubordinação do Inspetor Comandante. Para alcançar tais objetivos, Freeling desenhou um pacto simbólico com os próprios masqueraders. Através do discurso e da retirada da polícia das ruas, o governador anunciava que sua intensão não era interferir nas práticas dos carnavalescos e que reconhecia suas demandas. Ao mesmo tempo, exigia colaboração, respeito à ordem e lealdade ao governo. Pelo lado do governador, o pacto foi satisfatório nesse primeiro momento, garantindo que o carnaval transcorresse sem novos conflitos sangrentos e conseguindo isolar Baker. Veremos como esse pacto simbólico foi tratado pelos próprios carnavalescos no próximo tópico.

Não foi muito difícil colocar a polícia como rival dos masqueraders. A população negra de Port-of-Spain possuía rivalidade antiga com o corpo policial. Mr. Hamilton, representante designado pelo Colonial Office para realizar inquérito sobre as causas da revolta, recolheu informações significativas sobre a história de tensões e rivalidades entre esses grupos. Segundo ele, dois pontos agravariam a rivalidade entre o povo e a polícia. Primeiro, a "força é

\section{GANPHLAC}


amplamente composta por Barbadianos que não são apreciados pelos Trinitário" (CO 884/4); segundo, apenas alguns policiais

\begin{abstract}
compreendem o patois francês e espanhol que é falado pela maior parte da classe de pessoas que eles têm que lidar. Pelo que tenho afirmado acima, Vossa Senhoria irá perceber quão facilmente hostilidade pode ser gerada entre o povo e a polícia, e que uma causa muito menor teria efeito aqui do que seria necessária em um país onde a polícia é retirada [drawn] do povo, e tem a simpatia e o suporte moral de todos que estão interessados em manter a lei e a ordem. (CO 884/4)
\end{abstract}

Por conta da proximidade com as ilhas Windward e sua prosperidade na produção de açúcar e disponibilidade de terras, Trinidad se tornou polo de imigrantes negros do caribe, como visto anteriormente (CLARKE, 2011, p. 272). Os barbadianos representaram o maior grupo de imigrantes vindos das ilhas vizinhas. Em sua ampla maioria, eram negros com tradições culturais semelhantes. Em 1901, correspondiam a 45\% de todos os imigrantes caribenhos que viviam em Trinidad, com 18.822 pessoas (Trinidad... 1906, p. 24). Muitos conflitos se estabeleceram entre barbadianos e trinitários, especialmente porque os primeiros se recusavam a trabalhar em tempo integral nas fazendas de açúcar e preferiam competir por empregos nas cidades; muitos acabaram ocupando cargos na polícia, o que os colocou em posições de autoridade (LIVERPOOL, 2001, p. 255).

Nesse contexto de rivalidade e desconfiança, as medidas tomadas por Baker e executadas por essa força policial foram rapidamente compreendidas como ataque direto às tradições e costumes da população.

Se o Conselho Municipal e o governador perceberam as atitudes de Baker como as grandes responsáveis pelo conflito, entre os próprios masqueraders essa relação seria ainda mais tensa com o contato constante e direto entre policiais e os próprios sujeitos da festa nas ruas estreitas da cidade. Em carta ao governador, no dia 09 de março, mais de uma semana após a revolta, Baker pede "em nome da Força Policial" que se aponte uma comissão para investigar as circunstâncias e as origens dos últimos distúrbios e "o ataque sobre a Polícia". O encerramento da carta revela que a tensão das ruas e o ressentimento contra a polícia ainda estavam elevadíssimos:

Meus oficiais de baixa patente e soldados estão diariamente sujeitos ao arremesso de pedras, e ao escárnio e insultos do público mais baixo [lower public], e notícias falsas

\title{
GANPHLAC
}


estão circulando sobre meu comportamento pessoal durante os últimos distúrbios, os quais eu não tive a oportunidade de refutar.

Minha esposa e filhos também estão sendo insultados onde quer que eles apareçam nas ruas. (CO 29528935 )

Os masqueraders já haviam costurado suas estratégias de ação. Nela, Baker personificava a intransigência e a violência que enfrentavam diariamente nos Barrack Yards. Por outro lado, aproximam-se dos representantes de uma elite crioula francesa, personificada nos representantes do Conselho Municipal, das classes médias negras e de cor através dos jornais e usam a palavra do governador, como veremos a seguir.

\section{Costume, direito, Revolta e Carnaval}

Ao folhear os velhos papéis coloniais e ler as surradas páginas dos jornais de Port-ofSpain, encontramos recorrentemente dois termos sempre se referindo aos grupos populares e suas ações: Mob [turba, multidão] e Riot [motim, revolta] parecem resumir, para aqueles que as escrevem, tudo o que o povo é e faz: uma multidão ou turba que se amotina e revolta violentamente sem sentidos claros.

Entretanto, o historiador não deve ser levado a compreender a realidade histórica através das limitações impostas por estes termos. Segundo Thompson (1998, p. 151-153), mob e riot são termos "vagos que podem levar a uma visão espasmódica da história, negando à gente comum o papel como agente histórico". Para muitas pesquisas históricas, "o ‘motim' da 'turba' seria apenas uma reação a estímulos econômicos [elevação dos preços, fome, etc.]", enquanto a gente comum responderia a tais pressões econômicas com violência quase irracional.

Mas essa interpretação silencia aquilo que mais deve nos interessar: a racionalidade por trás das ações populares, a lógica, os sentidos e tensões no interior desses movimentos. Para Thompson, é possível perceber em quase toda ação popular na Inglaterra do século XVII uma "noção legitimadora": “[...] os homens e as mulheres da multidão [mob] estavam imbuídos da crença de que estavam defendendo direitos ou costumes tradicionais; e de que, em geral, tinham apoio do consenso mais amplo da comunidade.” (THOMPSON, 1998, p. 152). Os motins de fome - objetos da análise do historiador inglês - eram, assim, uma forma altamente complexa

\section{CANPHLAC}


de ação popular direta, disciplinada e com objetivos claros. As queixas operavam dentro de um consenso popular a respeito do que eram práticas legítimas e ilegítimas, normas e obrigações sociais.

Os masqueraders de Port-of-Spain não consistiam numa turba acéfala que reagia impulsivamente a ataques da polícia, não eram uma multidão amotinada incapaz de compreender os sentidos de suas ações - como os termos mob e riot poderiam implicar. Eles foram sujeitos de sua história na qual, através de sentidos próprios de legitimidade construídos em sua experiência social, decidiram deliberadamente se opor ao que consideravam injusto.

Um termo que pode abrir caminho para compreendermos melhor os sentidos da Revolta Canboulay de 1881 é costume. Segundo Thompson, costume pode ser definido como “[...] crenças não escritas, normas sociológicas e usos asseverados na prática, mas jamais registrados por qualquer regulamento" (THOMPSON, 1998, p. 88). O autor afirma que:

No século XVIII, o costume constituía a retórica de legitimação de quase todo uso, prática ou direito reclamado. Por isso, o costume não codificado - e até mesmo o codificado - estava em fluxo contínuo. Longe de exibir a permanência sugerida pela palavra 'tradição', o costume era um campo para a mudança e a disputa, uma arena na qual interesses opostos apresentavam reivindicações conflitantes. (THOMPSON, 1998, p. 16-17)

Logo, o costume não deve ser entendido apenas como a representação de uma tradição imóvel, mas como o cerne da retórica de legitimação das práticas sociais. Como as relações sociais estão sempre em constante conflito e transformação, o costume também está em fluxo contínuo e representa uma verdadeira arena de conflitos. Em muitos momentos e lugares, o costume apresenta afinidades com o direito consuetudinário, e esse mesmo deriva dos costumes de um país, “[...] usos que podiam ser reduzidos a regras e precedentes, que em certas circunstâncias eram codificados e podiam ter força de lei.” (THOMPSON, 1998, p. 15)

Um grupo que luta e resiste em nome de um costume, como os masqueraders empenhados em preservar o Canboulay, aparentemente seria conservador e contrário aos "avanços", à "modernidade". Devemos tomar cuidado com essa conclusão, não pelo fato de os próprios agentes coloniais, forças policiais e representantes das elites de Port-of-Spain concordarem com ela, mas porque ela desconsidera os conflitos e experiências sociais dos

\section{CANPHLAC}

Revista Eletrônica da ANPHLAC, ISSN 1679-1061, №. 20, p. 48-77, Jan/Jun., 2016.

http://revista.anphlac.org.br 
próprios sujeitos históricos. Mais uma vez, Thompson esclarece como essa cultura "tradicional" é "ao mesmo tempo rebelde".

\begin{abstract}
A cultura conservadora da plebe quase sempre resiste, em nome do costume, às racionalizações e inovações da economia (tais como cercamentos, a disciplina de trabalho, os 'livres' mercados não regulamentados de cereais) que os governantes, os comerciantes ou os empregadores querem impor. A inovação é mais evidente na camada superior da sociedade, mas como ela não é um processo tecnológico/social neutro e sem normas ('modernização', 'racionalização'), mas sim a inovação do processo capitalista, é quase sempre experimentada pela plebe como uma exploração, a expropriação de direitos de uso costumeiro, ou a destruição violenta de padrões valorizados de trabalho e lazer. Por isso, a cultura popular é rebelde, mas o é em defesa dos costumes. (THOMPSON, 1998, p. 19)
\end{abstract}

Considerações preciosas do historiador inglês. A Revolta Canboulay de 1881, quando pensada nesses marcos, é um exemplo significativo de como a população negra da cidade de Port-of-Spain estava interpretando os debates acerca do papel do carnaval na sociedade e como deveriam lutar para garantir seus costumes. A defesa do costume, nesse caso a prática do Canboulay, confrontava diretamente as inúmeras tentativas de "modernização" da sociedade, processo esse que passava diretamente pela europeização dos padrões de comportamento, beleza e lazer. Desde a década de 1840, inúmeros ataques foram feitos contra as práticas negras da cidade, desde a perseguição aos obeahmen até a tentativa de proibir o carnaval durante o governo de Keate nos anos 1850, gerando resistência popular. Nos jornais, era comum a campanha pela extinção definitiva do carnaval, festa que representaria o barbarismo, a selvageria e afastava Trinidad do caminho da civilização.

Apesar desse esforço em controlar, inibir, proibir e punir as práticas do carnaval negro, consideradas bárbaras e incivilizadas, contrárias à modernidade pretendida pelos trinitários que buscavam maior identificação com o império inglês, o Canboulay e as demais práticas do carnaval negro perduraram mesmo após a lei de 1868, encontrando-se no auge quando o Capitão Baker tenta acabar com elas entre 1877 e 1881.

É com base na Ordinance de 1868 que Baker irá justificar suas ações contra o Canboulay. Sua leitura é simples: a lei de 1868 proíbe o porte de tochas nas ruas, logo, é preciso impedi-lo, mesmo que através da violência. Por outro lado, os masqueraders compreendiam esse costume como um direito conquistado que, apesar da lei de 1868, eles sempre mantiveram.

\title{
GANPHLAC
}

Revista Eletrônica da ANPHLAC, ISSN 1679-1061, №. 20, p. 48-77, Jan/Jun., 2016.

http://revista.anphlac.org.br 
A noção do Canboulay enquanto direito parece ter sido tão forte nas ruas da cidade que mesmo as autoridades coloniais perceberam assim. Nas palavras do governador Freeling:

\begin{abstract}
Eles [o conselho municipal] também informam a existência de um forte sentimento contra a Polícia e que a multidão $[m o b]$ que se reunia anunciou abertamente sua intenção de resistir, pois ao povo ao longo dos últimos anos tem sido permitido a carregar tochas para seu divertimento no Carnaval que da única vez que o governo tentou interferir [durante a administração do Governador Keate quando Tropas Militares foram convocadas] os soldados e a polícia foram forçados a se retirar. (CO 29528929 , grifos meus)
\end{abstract}

Essa noção de que o uso de tochas era um costume que já havia se tornado um direito fica ainda mais evidente na carta enviada pelo Conselho Municipal para o governador. Nela, encontramos as seguintes conclusões:

\begin{abstract}
O povo estava sob a impressão de que eles estavam se preparando para defender direitos inquestionáveis, que de uma forma ou outra se espalhou que a polícia iria interferir para evitar Cannes Brulées, uma procissão com tochas acesas com a qual o Carnaval sempre tem início (...) o ataque ao povo buscou ser justificado pelo fato de que a polícia estava apenas fazendo seu dever de prevenir o ilícito porte de tochas acessas, a deputação acredita que foi uma surpresa para o povo que concebiam que tinham direito [they had the right] de portar tochas, que o decreto [proclamation] permitindo o carnaval não proibiu expressamente o porte de tochas, e que as tochas têm invariavelmente acompanhado o Cannes Brulées; que as tochas não eram mais ilegais do que o próprio Carnaval, e que a permissão de um [durante os dois dias de carnaval] acarretava na do outro. (CO 295289 29, grifos meus)
\end{abstract}

As frases destacadas nessa fonte são muito importantes para a compreensão dos sentidos da revolta para os próprios masqueraders. O estudo das ações populares, especialmente de sua cultura, é reconhecidamente mais trabalhoso e difícil, justamente pelo fato de termos poucas fontes produzidas diretamente por eles. Novamente aqui, temos uma fonte produzida por membros das elites que falam "pelos" sujeitos da ação. Entretanto, como já demonstrado por tantos outros pesquisadores (GINZBURG, 2007; PERROT, 2001; DAVIS, 1990), isso não inviabiliza nosso trabalho. No caso da Revolta Canboulay de 1881, o argumento dos masqueraders se fez tão forte e claro que conseguiu atingir os ouvidos do próprio governador, autoridade máxima da colônia. Ficou evidente que os masqueraders lutavam para garantir a autonomia festiva, o costume tradicional e o direito de festejar de sua maneira.

Também é importante perceber que o argumento desses sujeitos, reproduzido na fonte acima pelo Conselho Municipal, também se valia de normas escritas. Segundo o Conselho

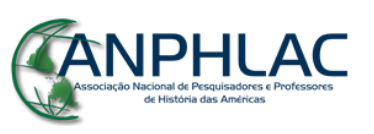


Municipal, os carnavalescos teriam justificado a ilegitimidade da ação da polícia através do uso da Proclamation assinada pelo próprio Capitão Baker, regulamentando o carnaval de 1881. Este edital, publicado em 17 de fevereiro de 1881, não falava expressamente sobre uso de tochas pela população. Logo, não estaria proibida. O edital, apesar de citar e dizer que está baseado na lei de 1868, atenta apenas para os dias e horários em que seria permitido o uso de máscaras e "chama atenção" para o artigo $5^{\circ}$ do decreto que afirma que "um assalto cometido por qualquer pessoa mascarada ou de outra forma disfarçada é punível com pena de prisão com trabalhos forçados por qualquer período não superior a seis meses". E encerra dizendo que "qualquer folião [masquerader] culpado de comportamento indecente ou que aparecer em qualquer disfarce indecente ou ofensivo será processado" (CO 295289 49).

O próprio governador Freeling, depois de ouvir as considerações do Conselho Municipal e discursar diretamente para os masqueraders na praça do mercado, conclui que as "ordens mais baixas dessa Ilha [...] começam a considerar um direito [o Canboulay] embora previamente tratado com maior ou menor indiferença" (CO 295289 49).

A percepção do Canboulay como um direito adquirido parece ter extrapolado os limites dos cortejos das Yard bands. Antes de essa noção atingir as reuniões do Conselho Municipal e o gabinete do Governador, já havia sido compreendida por parcela mais ampla da população da cidade. Durante a luta inicial entre masqueraders e policiais, a participação de espectadores, tanto nas ruas quanto das sacadas das casas, foi importante. Segundo Baker,

Garrafas e pedras foram atiradas por passantes e das casas dos espectadores, e essas pessoas eram atacadas pela Polícia; e enquanto em perseguição da multidão, garrafas, pedras, etc. foram jogadas na Polícia das casas de cada lado das ruas por onde tinham de passar. Sem dúvida, alguns espectadores podem ter sido feridos. (CO 295289 49)

Além da participação direta no ataque à polícia, que ocasionou a destruição de lâmpadas públicas nas ruas onde os principais conflitos ocorreram - Duke, Park, George, Charlotte, Duncan e Upper Prince -, pessoas que não compunham naquele momento os grupos do Canboulay destruíram lâmpadas em outras partes da cidade, sem motivo conhecido na interpretação de Baker:

As lâmpadas nas outras partes da cidade foram quebradas por grupos de dois ou três que pareciam especialmente contratados para o efeito. A razão para o último processo

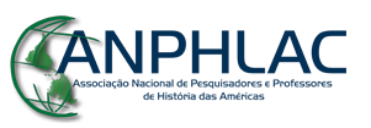

Revista Eletrônica da ANPHLAC, ISSN 1679-1061, №. 20, p. 48-77, Jan/Jun., 2016.

http://revista.anphlac.org.br 
não estou neste momento preparado para dar, mas eu estou na esperança de que num dia não muito distante eu vou ser capaz de fornecer o motivo. (CO 295289 49)

No dia 21 de março de 1881, respondendo a um conjunto de perguntas enviadas pelo governador, o comissário de polícia da Província Norte, Mr. Wilson, afirma que naquele carnaval a ação dos grupos de "rufiões" teria sido diferente:

pois todas as bandas se reuniram para enfrentar a polícia, e expulsá-la da cidade. Garrafas e pedras foram acumuladas em casas e ruas. Chama atenção para o fato de que mesmo os mascarados inofensivos e pessoas que não eram das classes baixas também apoiaram os brutos. (CO 295289 49)

Impressiona-lhe, então, o fato de os "brutos" terem se unido pela primeira vez - e Mr. Wilson arroga a prerrogativa de conhecer bem a história do Carnaval, visto que chegou a colônia em 1869 - e terem recebido apoio inclusive dos foliões que não costumavam se engajar no Canboulay e de grupos "que não eram das classes baixas". Essa configuração inédita do carnaval de Port-of-Spain era justificada pela "crença universal por parte da multidão de que a Polícia iria colocar um fim em todas as práticas carnavalescas”. Assim como Baker, Mr. Wilson era incapaz de atribuir à multidão $[\mathrm{mob}]$ a autonomia do ato. Para ele, as ações violentas teriam sido incentivadas e incutidas na cabeça da multidão por alguns indivíduos influentes, "mesmo proprietários de um ou dois jornais locais”. Alguns jornalistas estariam fazendo terrorismo sobre parte do público, inclusive aventando "falsas questões de cor", podendo com isso induzir ao erro uma grande parcela do público. Suas ações maliciosas seriam as reais responsáveis pelos distúrbios (CO 295289 52).

\section{Falsas questões de cor: raça, cultura e classe em Port-of-Spain}

"Falsas questões de cor". Essa frase nos possibilita discutir melhor as relações entre raça, classe e cultura nessa sociedade. Até aqui, vimos nas fontes que são raras as vezes em que termos raciais são utilizados para descrever pessoas. Essa característica revela, mais do que a ausência de práticas racistas, a sutiliza na utilização de termos raciais em sociedades pósabolição e/ou sob regime colonialista. No caso de Trinidad, entre 1838 e 1881, a utilização de

\section{GANPHLAC}

Revista Eletrônica da ANPHLAC, ISSN 1679-1061, №. 20, p. 48-77, Jan/Jun., 2016.

http://revista.anphlac.org.br 
termos como "lower classes" referem-se amplamente aos grupos de trabalhadores negros, homens e mulheres que compunham a grande maioria da população da ilha no período.

Portanto, em Trinidad do século XIX, o termo "lower class" estava profundamente ligado à população negra e sua cultura. No carnaval, não era diferente: a população que formava os grupos de Canboulay, aqueles chamados de Jamettes, os alvos do olhar repressivo, eram majoritariamente negros. A cultura associada às "lower classes" de Port-of-Spain era, dessa forma, uma cultura negra. Por isso, quando as fontes falam em "people", "mob", "poor classes" estão falando também de uma determinada percepção racializada da sociedade.

Entretanto, o discurso público de jornalistas e autoridades coloniais buscava constantemente evitar racializar a repressão, justificando-a através de argumentos culturais primitivismo, práticas incivilizadas ou bárbaras - ou sociais - classes pobres, violentas e obscenas que precisam ser controladas para a manutenção da ordem. Por isso, a crítica intensa por parte do comissário de polícia em direção aos supostos jornalistas que tentavam associar a ação repressiva da polícia à questão racial.

A Revolta Canboulay de 1881, portanto, foi compreendida por parte das autoridades coloniais e imprensa como uma luta pela manutenção de um direito, assim entendido pelas "lower classes" da cidade. O que não parece ter sido compreendido mais a fundo por esses interlocutores foram os motivos que levavam esse costume, compreendido como direito, ser tão bravamente defendido nas ruas da cidade naquele carnaval. O Canboulay era uma prática recheada de simbolismo, calcada na festa pela abolição da escravidão; trazia para as ruas uma performance pública de memórias do cativeiro e da conquista da liberdade; representava a formação de identidades, alianças e rivalidades que eram a base da experiência cotidiana da população negra dos barrack yards de Port-of-Spain.

Assim, a luta com cacetes, pedras, garrafas, canções e tambores não era apenas pela manutenção do costume "irracional" de carregar tochas pelas ruas. Nem uma ação manipulada por donos de jornais. Mas sim uma batalha por espaços de autonomia, identidade e participação numa sociedade que constantemente impunha limites à cidadania dos negros e buscava silenciar e destruir suas práticas, por não se adequarem aos padrões da "modernidade" europeia pretendida por boa parte das elites coloniais.

Essa batalha não se daria apenas em Trinidad. Por todo Caribe, nas colônias francesas e inglesas, ao longo do século XIX, os ex-escravos e seus descendentes se empenharam em

\section{GANPHLAC}


conquistar espaços de representatividade e exercer sua cidadania. Essa luta seria muito intensa e difícil, visto que, segundo Douglas Hall, em nenhum lugar, “[...] nem nos círculos de governo coloniais ou metropolitanos[,] houve qualquer disposição para admitir a cidadania política total para os recém-emancipados" (HALL, 2011, p. 47). E o temor de uma assembleia legislativa controlada por negros conseguia unir tanto representantes metropolitanos quanto as variadas vertentes das elites locais. Assim, conclui Hall, “[...] politicamente, no Caribe Britânico, todas as classes permaneceram como livres cidadãos Britânicos nas colônias, mas claramente desiguais" (HALL, 2011, p. 49).

Os masqueraders, sujeitos da Revolta do Canboulay de 1881, eram cidadãos livres do império Britânico. Contudo, sua cidadania era limitada tanto pela impossibilidade de participar das decisões políticas de sua sociedade quanto pelas leis que criminalizavam suas práticas sociais e culturais. As elites da colônia também não votavam para escolher seus representantes. Contudo não tinham seus modos de vida, o direito de ir e vir, suas festas e formas de falar transformadas em alvo constante de leis repressivas e da arbitrariedade policial - como acontecia com a população negra. A Revolta, portanto, não foi um ato de reação impensado e impulsivo, mas sim uma ação política em defesa de um dos poucos espaços conquistados para expressar a cidadania negra no Pós-Abolição.

A pressão negra nas ruas através da união entre os grupos tradicionalmente rivais e o ataque à polícia possibilitou o estabelecimento do pacto simbólico com o governador, onde a polícia foi responsabilizada, e o direito de continuarem o carnaval "sem interferência" foi assegurado pelo representante da coroa britânica em praça pública. Numa sociedade onde os mecanismos de representação eram muito limitados, especialmente para os não-brancos em geral, o empenho em defender o Canboulay denota o desejo por autonomia e liberdades civis, tão caras para a cidadania e tão escassas na ilha.

A Revolta de 1881 não garantiu a cidadania plena aos masqueraders de Port-of-Spain, contudo, acelerou um processo de transformações na festa e possibilitou novas formas de relação entre seus sujeitos e os agentes coloniais, a imprensa e a sociedade como um todo. Os rumos do carnaval de Port-of-Spain seriam outros, as vidas dos masqueraders também, alcançando ao longo do século XX a posição de símbolo máximo da identidade nacional da República da Trinidad e Tobago, mas esse enredo já não cabe aqui.

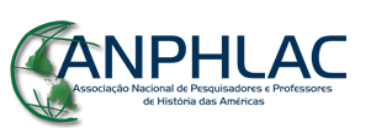

Revista Eletrônica da ANPHLAC, ISSN 1679-1061, №. 20, p. 48-77, Jan/Jun., 2016.

http://revista.anphlac.org.br 


\section{Referências Bibliográficas}

ASSUNÇÃO, Matthias Röhrig. Versos e Cacetes: Desafios masculinos na cultura popular afro-fluminense. Paper apresentado ao IX Congresso da Brazilian Studies AssociationBRASA, Tulane University, New Orleans, 27-30 de março, 2008.

BRADING, D. A. Bourbon Spain and its American empire. In: BETHELL, L. (Org.). The Cambridge History of Latin America. Cambridge: Cambridge University Press, 1984.

BRASIL, Eric. Carnavais atlânticos: cidadania e cultura negra no pós-abolição. Rio de Janeiro e Port-of-Spain, Trinidad (1838-1920). Tese de doutorado. Programa de Pós-Graduação em História da Universidade Federal Fluminense. Niterói, 2016.

BRERETON, B. Race Relations in Colonial Trinidad 1870-1900. Cambridge: Cambridge University Press, 2002.

CLARKE, C. Demographic Change and Population Movement. In: LAURENCE, K. O. (Org.). General History of the Caribbean, Vol IV: The long Nineteenth Century: Nineteenth Century Transformations. Paris: UNESCO / Londres: Macmillian Educational, 2011.

COWLEY, J. Carnival, Canboulay and Calypso: Traditions in the Making. Cambridge: Cambridge University Press, 2003.

. Music \& migration: aspects of black music in the British Caribbean, the United States, and Britain, before the independence of Jamaica and Trinidad \& Tobago. University of Warwick, 1992.

CROWLEY, D. J. The Traditional Masques of Carnival. Caribbean Quarterly, 4(3), p.194-223, 1956.

CUDJOE, S. R. Beyond Boundaries: The Intellectual Tradition of Trinidad and Tobago in the Nineteenth Century. Wellesley: University of Massachusetts Press, 2003.

DAVIS, N. Z. Culturas do Povo: Sociedade e Cultura no Início da França Moderna. Rio de Janeiro: Paz e Terra, 1990.

DUDLEY, S. Music from behind the Bridge: Steelband Aesthetics and Politics in Trinidad and Tobago. New York: Oxford University Press, 2007.

ELDER, J. D. Cannes Brûlées. TDR (1988-), 42(3), p. 38-43, 1998.

FERGUS, C. Dread of Insurrection: Abolitionism, Security, and Labor in Britain's West Indian Colonies, 1760-1823. The William and Mary Quarterly, 66(4), p. 757-780, 2009.

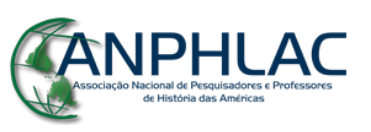

Revista Eletrônica da ANPHLAC, ISSN 1679-1061, №. 20, p. 48-77, Jan/Jun., 2016.

http://revista.anphlac.org.br 
Revolutionary Emancipation: Slavery and Abolitionism in the British West Indies. Lousiana: Baton Rouge: Louisiana State University Press, 2003.

GINZBURG, C. O fio e os rastros: verdadeiro, falso, fictício. São Paulo: Companhia das Letras, 2007.

HALL, D. A Population of Free Persons. In: LAURENCE, K. O. (Org.). General History of the Caribbean, Vol IV: The long Nineteenth Century: Nineteenth Century Transformations. Paris: UNESCO / Londres: Macmillian Educational, 2011.

LIVERPOOL, H. C. Rituals of Power and Rebellion: The Carnival Tradition in Trinidad and Tobago, 1763-1962. Chicago: Research Associates School Times, 2001.

MATTHEWS, G. Trinidad: A Model Colony for British Slave Trade Abolition. Parliamentary History, 26(4S), p. 84-96, 2007.

PEARSE, A. Carnival in Nineteenth Century Trinidad. Caribbean Quarterly, 4(3), p. 175-193, 1956.

PERROT, M. Os excluídos da história: operários, mulheres e prisioneiros. Rio de Janeiro: Paz e Terra, 2001.

SAMAROO, B. The imigrant Communities. In: LAURENCE, K. O. (Org.). General History of the Caribbean, Vol IV: The long Nineteenth Century: Nineteenth Century Transformations. Paris: UNESCO / Londres: Macmillian Educational, 2011.

THOMPSON, E. P. Costumes em comum. São Paulo: Companhia das Letras, 1998.

Trinidad Tourist Guide and Commercial and Professional Register of Port-of-Spain, Port-ofSpain: Trinidad Advertising Company, 1906.

TROTMAN, D. V. Crime in Trinidad: Conflict and Control in a Plantation Society, 1838-1900. Knoxville: University of Tennessee Press, 1986.

WADDELL, D. A. G. A política internacional e a independência da América Latina. In: BETHELL L. (Org.). História da América Latina, vol. 3. São Paulo: Edusp, 2004.

WILLIAMS, E. History of the people of Trinidad \& Tobago. New York: Praeger, 1964.

WOODING, H. O. B. The Constitutional History of Trinidad and Tobago. Caribbean Quarterly, 6(2/3), p. 143-159, 1960.

\section{GANPHLAC}

Revista Eletrônica da ANPHLAC, ISSN 1679-1061, №. 20, p. 48-77, Jan/Jun., 2016.

http://revista.anphlac.org.br 